\title{
Reality in Dutch Novels: Developing a Postmodern Literary-Based Ontology
}

\author{
Christiaan Prinsloo \\ Seoul National University, Seoul, South Korea
}

\begin{abstract}
The term "ontology" is used to describe the nature of reality and demarcates the parameters of existence. An understanding and description of ontology is crucial for academic pursuit as it unveils applicable realities, yet it is often disregarded. The general neglect of ontology provided three motivations for this paper: Firstly, the discussion of the ontological underpinnings in research papers is often neglected while the methodology and methods receive extensive review. Secondly, tertiary students in an academic research-writing course face tremendous difficulty to describe the philosophical ideas that support their interpretation of reality and existence. Thirdly, the philosophical underpinnings of contemporary ontological thought are further complicated by the epistemological challenges posed by the tension between modernism and postmodernism. This paper suggests the use of literature (novels) as a relativity accessible platform to initiate the development of ontological thought. Through a close reading of a sample of Dutch novels published during the last decade of the 20th century, three themes were developed to illuminate the nature of postmodern reality and establish a literary-based ontology. The following three themes were developed: reality as fragments of fiction, reality as dream of paradoxes, and reality as plethora of stories. By using literature as source, ontological thought can be developed to illuminate the extent of the realities acknowledged in research projects.
\end{abstract}

Keywords: postmodernism, ontology, reality, stories, literature, hermeneutic phenomenology

\section{Introduction}

"We are living in a new world, a world that does not know how to define itself by what it is, but only by what it has just-now ceased to be” (Anderson, 1997, p. 6). Such was the tumult and apprehension accompanying postmodernity that it was difficult to describe postmodernism without reference to and/or comparison with modernism. Postmodernism has been described as anti-modernist; therefore, it appeared to be against the "autonomous aesthetic, of a radically anti-representational self-reflexivity" of modern artistic endeavors (Bertens, 1995, p. 3). Postmodernism of the 1960s is characterized by an "attitude" or "new sensibility" that is eclectic, democratic, and profoundly political (Bertens, 1995, p. 5). In the 1970s, postmodernism developed two influential strands of thought, namely, deconstructionist and poststructuralist postmodernism. The late 1970s and early 1980s is characterized by deconstructionist postmodernism, heavily influenced by the philosophies of Barthes and Derrida. Deconstructionism is linguistic in nature and considers the text as a multidimensional, intertextual space. Poststructuralist postmodernism of the 1980s is often associated with the philosophies of Foucault and Lacan.

Christiaan Prinsloo, Ph.D., Assistant Teaching Professor, Faculty of Liberal Education, Seoul National University, South Korea. 
Similar to deconstructionism, poststructuralist postmodernism supports textual realities (ontologies) where language is not representational; instead, language constitutes or creates realities. This form of postmodernism uncovers the politics that create institutional hierarchies, and it contests the hegemony of metanarratives because it promotes "difference, pluriformity, and multiplicity" (Bertens, 1995, p. 7). By the 1990s, postmodernism has become synonymous with Lyotard's (1984, p. xxiii) description of it as a condition that is incredulous toward post-Enlightenment grand theories or metanarratives that advocate singular realities, hierarchies, determinacy, and objective truth (Malpas, 2005, pp. 7-8).

Today, some scholars argue that the postmodern condition in literature and culture is dead, or only fragments of it continue in contemporary society as it induces critical perspectives (Kirby, 2006, p. 34; Ning, 2013, p. 296) or metamodernism (Vermeulen \& Van den Akker, 2015, p. 55). Despite the notion that postmodernism may be waning, its pervasive ramifications of eclectic themes in literature cannot be omitted. Preliminary research revealed that Dutch literature published during the last decade of the 20th century exhibits at least four postmodern themes, namely, the ambiguity of reality, proliferation of social turmoil, mystification of identity, and ubiquity of intertextuality. Although a broad understanding of a postmodern ontology is subject to more than just the above-mentioned themes, in the interest of congruency and cohesiveness, this paper focuses on the ambiguity of reality as emblematic of a postmodern literary-based ontology. Therefore, the purpose of this paper is to discover and describe a postmodern literary-based ontology through a close reading of a sample of late 20th century Dutch novels.

In order to clarify the purpose statement, it would be prudent to reify the meaning of postmodern, literary, and ontology. The brief introduction provides the platform from which the discussion section departs to investigate the meaning of postmodernism as derived from late 20th century Dutch novels. It would therefore be premature to "describe" postmodern at this stage. Literary or literature, for the purposes of this paper, refers to novels or narrative prose fiction of book length (Cuddon, 1992, pp. 505, 599). This means that other genres, such as short stories, poetry, and dramas were excluded. Ontology (worldview) could be described as a "general philosophical orientation" (Creswell, 2014, p. 6) by which one attempts to comprehend the realities of existence (Noonan, 2008, p. 577); therefore, ontology is a "sensemaking activity” (Eskridge \& Hoffman, 2012, p. 58). ${ }^{1}$ Some of the most influential ontological paradigms include positivism, constructivism, transformative perspectives, and pragmatism (Creswell, 2014, p. 6). The postmodern literary-based ontology draws primarily on literature and philosophy to make an ontological contribution across these ontological paradigms.

The motivation to investigate ontology (to question what exists and what is real) as subject matter for this paper is threefold: (1) a general neglect among researchers to explicate ontological decisions for their research; (2) the difficulty that students experience to conceptualize their ontological views; and (3) the epistemological repercussions of postmodernism provide such impetus.

Firstly, although often neglected or summarily replaced by statistical-empirical methods, ontology is particularly important in social scientific research because it prompts the (empirical) researcher to ask a fundamental question: "How did the given social reality come to be constituted as it appears?" (Noonan, 2008, p. 578). In the business sciences, for example, the neglect of ontological choices in research may lead to "superficiality” and “overly descriptive” narrative accounts (Peters, Pressey, Vanharanta, \& Johnston, 2013, p.

\footnotetext{
${ }^{1}$ The philosophical meaning of ontology should not be confused with its meaning in poetry. According to Cuddon (1991, p. 657), ontology refers to the texture and structure of a poem that provide meaning.
} 
336). In nursing science, Lopez and Willis (2004, p. 726) caution that scholarship neglects to "identify the philosophical [ontological] assumptions" that underlie the research. They also emphasize the importance of ontological descriptions as instrumental to evaluate the epistemological contributions of research studies.

Secondly, over the past three years, it has come to my attention that university students in the advanced academic research-writing course struggle to conceptualize their ontological views. An explicit introduction on the most common worldviews is provided during this course, yet students find it challenging to understand the purpose of ontology, conceptualize their own worldviews, and integrate it into their research. The abstract nature of ontological views serves as motivation to utilize the familiarity of literature or stories as pedagogic tool.

The third motivation for this paper emanates from the epistemological consequences of postmodernism and anticipates a literary-based ontology. Because local narratives discredit authoritative history (metanarratives), reality becomes delegitimized by textualized, hyper-real simulations (Cahoone, 1995, p. 8), or as the protagonist in De erfenis announces with ubiquitous wisdom: "I'll be waiting for you in the book" (Palmen, 1999, p. 96). As traditional distinctions between "real" and "fictitious" and "true" and "false" deteriorate, the nature of knowledge is questioned. These traditional boundaries become obscured as the contemporary information surplus leaves one with a "sense of unknowing" (Widdowson, 1999, p. 152). Consequently, the nature of knowledge (epistemology) is contemplated. The perplexity caused by the sheer amount of information and obfuscation of reality and fiction is the result of the lack of

[...] attendant "narratives" to explain, interpret and make sense of it [...]. "The literary”, I am claiming—precisely by way of its "forming" and "fashioning" properties, its "sense of subject", its identification of "patterns" and "knowable communities [...]" gives us insight into the complex interactive relations which comprise our culture. (Widdowson, 1999, p. 152)

That is, literature may suffice as an ontological underpinning to find meaning amidst the chaos of multiple realities.

In order to discover and describe a postmodern literary-based ontology, it is necessary to outline the research framework that facilitated the data collection and analysis. The research framework is followed by the discussion section that reports on the following three themes that illuminate a postmodern ontology: reality as fragments of fiction, reality as a dream of paradoxes, and reality as plethora of stories. The paper concludes with summative notes on the limitations of the investigation and possible future research initiatives that could arise from it.

\section{Research Framework}

The research framework consists of three main parts. Firstly, a hermeneutic (interpretive) phenomenological worldview underlies the ontological and epistemological assumptions of the research perspective. Secondly, a sample of late 20th century Dutch literature is considered as a case study methodology. Thirdly, the method of analysis is based on a close reading of the sample literature. The three components of the research framework are discussed in more detail to afford research transparency.

The philosophical assumptions that underpinned this paper are grounded in the hermeneutic phenomenology of Heidegger and Gadamer. ${ }^{2}$ This entails that "the researcher describes the lived experiences

${ }^{2}$ For an unambiguous exposition of the different strands of phenomenology, Dowling and Cooney (2012, p. 22) provide an insightful diagrammatic summary. In the interest of brevity, references are made only to the applicable hermeneutic phenomenological assumptions. 
of individuals about a phenomenon as described by participants” (Creswell, 2014, p. 14). Individuals and the world are considered as one entity in which "human experience and consciousness necessarily involve some aspect of the world as their object, which, reciprocally, provides the context for the meaning of experience and consciousness" (Seamor, 2000). Therefore, reality can be found in lived experiences (LeVasseur, 2003, p. 409). The descriptions of the trials and tribulations of characters in the novels served as the lived experiences from which common denominating phenomena were extrapolated as ontological themes of postmodernity. The ontological themes were interpreted considering at least the following three contexts: the theoretical contexts synthesized from scholarship, the literary contexts garnered from the novels, and the socio-cultural history of the researcher (Dowling \& Cooney, 2012, p. 25).

A case study methodology was selected because it configures the hermeneutic phenomenological ontology and facilitates the data collection method. As the ontology seeks the underpinnings of reality in the lived experiences of participants, a case study methodology attempts to "understand and interpret the world in terms of its actors" (Cohen, Manion, \& Morrison, 2005, p. 181). The methodology was conceptualized as an instrumental case study because the actual case, a sample of Dutch novels, was secondary to the wider issue under investigation and the outcome of the paper, namely, the postmodern ontology (Dörnyei, 2007, p. 152). The case study comprised a purposive sample of Dutch novels published during approximately the last decade of the 20th century. The sample novels were considered postmodern by virtue of being published during postmodernity; however, this does not mean that they do not exhibit devices associated with realism, modernism, or other movements. However, the objective of this paper is not to categorize the selected novels as realist, modernist, or postmodernist but to apprehend a postmodern ontology from their content. The most popular Dutch novels were selected based on the integration of the bestseller lists compiled by Francken (2001, pp. 113-135) and the annual Boekenweekgeschenk published between 1990 through 2000 (Allesopeenrij, 2015). Novels by the following authors, published during the designated timeframe, were included in the sample: Claus, Dorrestein, Giphart, Haasse, Hemmerechts, Mulish, Palmen, Ruebsamen, 't Hart, Van Dis, Wieg, and Zwagerman. The novels were subjected to a close reading to reveal the postmodern literary ontology.

The close reading method entailed the mindful and deliberate examination of the sample literature with the objective to identify themes (Bizzocchi \& Tanenbaum, 2011, p. 262; Brummett, 2009, p. 9). Themes emerged $a$ posteriori as the literature was explored and opened up. Extensive note taking accompanied the examination to enable cross-referencing among the novels. It would be erroneous to assume that the close reading was conducted objectively or that the researcher approached the topic as tabula rasa because the hermeneutic phenomenological ontology recognizes the researcher's involvement through co-constitutionality. Co-constitutionality means that hermeneutic phenomenology is the result of a synthesis of meanings expressed by participants (authors and characters) and the researcher. In agreement with the ontology, the meanings accounted for through the method were considered equally true as they contextualized the realities of the participants. The epistemological contribution of hermeneutic phenomenology lies in utilizing the derived meanings of interpretations for scholarship, education, and practice (Lopez \& Willis, 2004, p. 730). These contributions are addressed in the conclusion.

\section{Discussion}

As a continuation of the "theoretical" exposition in the introduction and as a result of the close reading of the sample novels, the discussion exposes the postmodern ontological themes that are intimately associated 
with reality or existence. Although various themes related to a postmodern ontology are addressed in the novels, this paper focuses on the exposition of reality as fragmented and fictitious, as a dream of paradoxes, and plethora of stories. The sequence of the discussion illustrates that the fragmentation of traditional conceptions of reality leads to a mesmerizing tolerance for paradoxes, and the proliferation of multiple paradoxical realities engenders a plethora of stories that result in a condition called story shock.

\section{Reality as Fragments of Fiction}

In general, modernist novels consider epistemological issues related to truth and knowledge; however, postmodern novels consider ontological questions that ponder the nature of reality (Malpas, 2005, p. 24). While traditional fiction is associated with "imaginative" prose that is distinct from nonfiction (Cuddon, 1991, p. 343), postmodern fiction is a paradox since "all reality is fiction” (Liebenberg, 1988, p. 275). To contemplate the nature of postmodern reality as fragments of fiction, this section investigates how power struggles with metanarratives result in social discontent. In turn, social upheaval fragments reality into seemingly paradoxical local narratives.

The conceptualization of postmodern reality is inextricably bound with the rejection of modernist metanarratives about epistemology or knowledge. The objective neutrality of knowledge celebrated by positivists and the emancipatory effect of knowledge advocated by the political left is suspended by postmodernists as they consider knowledge as inseparably connected to power (Bertens, 1995, p. 7). The poststructural postmodernist Foucault considers power as a multiplicity of complex relations that are strategically situated (Smart, 2002, p. 70). Such complex relations are especially evident in (post)colonial and immigrant narratives and could be interpreted as a challenge of the dominant elite. Because of its history, colonial and immigrant narratives are prevalent in Dutch literature. For example, in Sleuteloog (2002), the protagonist Herma Warner recollects her youth in Dutch-colonial Batavia. She was compelled to recall how her friendship with an Indonesian girl deteriorated as colonial power diminished. Warner describes the transition to Indonesian independence much in the same way that scholars characterize the turmoil and chaos of the transition to postmodernity: "[...] radical, stormy developments under the surface of apparent order that is not noticed or understood or incorrectly assessed by both the indigenous and European elite” (Haasse, 2002, p. 50). ${ }^{3}$

The power relations between the subjugated and the elite are maintained and perpetuated through existing and accepted forms of knowledge. Foucault coined the term "power/knowledge" to convey the idea that power is established through recognized forms of knowledge (Smart, 2002, pp. 72-74). These recognized forms of knowledge determine what is true and real. For instance, development aid provided by western powers creates the "reality" that developing countries are feeble and depended thus instilling a power hierarchy of superior and subordinate countries. In De zonnewijser such aid is characterized as a "hypocritical way to ease the conscience" (t'Hart, 2000, p. 99) for the atrocities associated with colonial rule. Similarly, homosexuality is undermined in De geruchten as the metanarrative of heterosexuality prefers not to "see such things" (Claus, 1997, p. 66). By accepting such aid and by metaphorically closing our eyes to other forms of existence, power relations and accepted forms of reality are maintained and solidified. However, the hegemonic modernist reality is challenged by postmodern thought.

\footnotetext{
${ }^{3}$ Direct quotations from the original Dutch novels were translated by the author to assist reading comprehension for a larger audience and to promote the fluidity of the text.
} 
A possible consequence of the postmodern challenge to modern metanarratives includes pervasive social discontent. By recognizing local or small narratives, alternative realities gain acknowledgment. One such example is drawn from the universally experienced school environment. Frustration with the collective acceptance of the division of school classes according to student performance and the artificial manipulation of time according to class periods is aptly expressed in De vriendschap: "Everyone obeys these structures as if they were natural phenomena" (Palmen, 1995, p. 38). However, the protagonist's challenge of the system is evident when she admits: "I often practice to think against the bell” (Palmen, 1995, p. 38). ${ }^{4}$ Or as the protagonist in De voorzitter speculates: "[...] nowadays nothing is holy, nothing is stable, nothing has eternal value” (Giphart, 1999, p. 52). As existing structures surrender their credibility, new realities come into existence that recognize: "[d]ifferent people in different positions at different moments will live in different realities” (Shotter, 1993, p. 17).

As the struggle for power leads to social discontent with existing structures, reality becomes increasingly fragmented. The fragmentation manifests in at least to manners, namely, genre structure and rhetorical expression. Genre structure is creatively manipulated by authors to fragment stories and realities symmetrically or asymmetrically. Mulish (1998; 2000) relies on playwriting structures to narrate De procedure according to a three-part play and Het theater de brief en de waarheid as two-part play with interlude. Asymmetrical structure is employed in I.M. because the plot line is secondary to the meaning of the narrative that consists of dialogues and thoughts shared between the author and protagonist (Palmen, 1999). Souffleurs van de duivel (Wieg, 1996) is an anthology of apparent short stories that could be read as novel because a first person narrator reappears in several stories. It appears as if the asymmetrical genre structure contributes to variegated rhetorical expression.

Characteristically, postmodern novels embrace multiple truths and toy with realities, either implicitly or explicitly to create colorful rhetorical expressions. In the preface of De overval readers are told that similarities between the novel and "external reality" are intended: "Nothing in this story is lied about. Everything happened exactly as I tell it, even amounts are exact” (Wieg, 1997, p. 24). A similar strategy is used in Palmwijn:

Similarities with islands along the west coast of Africa are not coincidental; even political situations drew on reality. However, readers won't find the islands described in Palmwijn on a map. A reader who recognizes himself in one of the characters has a more vivid imagination than the author. (Van Dis, 1996, preface)

Such is the nature of a postmodern literary ontology that it deliberately mystifies the distinctions between reality and fiction; it appears as a "reflection of an opaque newspaper photo" (Claus, 1997, p. 8), "faintly visible behind matted glass and blurred" (Haasse, 2000, p. 158). A novel that utilizes this strategy to distort the traditional margins between realities and truths could be called "historiographic metafiction" because it "comments on and investigates its own status as fiction as well as questioning our ideas of the relation between fiction, reality and truth” (Malpas, 2005, p. 26).

Reality and fiction play hide-and-seek in Ontaarde moeders as family secrets obscure memories of the past and question existential truths of the characters. A pivotal example is drawn from the rape of Meijken. As the memories of the reality of her rape become more vivid, the initial trauma mutates into an existential crises:

Slowly she lowers her head into her hands, hesitantly suppressing the images as they return one-by-one. Even her

\footnotetext{
${ }^{4}$ In addition to the explicit struggle with the social power structure, the protagonist in De vriendschap also narrates her experience with subtle, yet important, power relations in terms of friendships, sexuality, and linguistic competence. This illustrates the actualization of power-related challenges by postmodern literature.
} 
unconscious mind twists the facts. I am loosing myself, Meijken thinks startled. Soon I will be dead without knowing what was real and what was imagined. (Dorrestein, 1992, p. 111)

The author describes the relationship between reality and fiction as tense. A secretive paradox is the cornerstone of successful fiction where "imagination becomes reality as soon as it's written" (Dorrestein, 2002, p. 98). Fiction does not have to be true as long as it has the potential to be true. The laws that determine what is possible are revoked by fiction to merge with our understanding of reality as text.

In postmodern literature, the text does not have meaning because it is true; instead, the text is considered true because it holds meaning. Truth and reality exist because of the potential meanings of texts. This idea is aptly conveyed in Sleuteloog:

It is clear that facts and data are meaningless on their own. The true meaning is concealed in the fabric of subjective impressions that can barely be expressed in words, in the echo of past sensations and moods, and in the ever so real, but now the feeling evaporates like a dream [...]. (Haasse, 2002, p. 50)

In contrast to Dorrestein and in agreement with Haasse, Mulish (2000) challenges the legitimacy and supremacy of the written text. In Het theater de brief en de waarheid, the narrator ponders: "Perhaps I should write down what I would like to say, but for some or other reason something prevents me from doing so, as if it would be less true if it appeared in black and white" (Mulish, 2000, p. 16). Traditionally, the expression "in black and white" alludes to an official text or agreement that is true and real by virtue of being written. By summoning two characters from the dead to retell their collective history, Mulish adds multiple dimensions to an existing reality. Instead of declaring one character's retelling as true and the other character's perspective as fiction, a postmodern approach considers them as "two irreconcilable truths" (Mulish, 2000, p. 80) or two possible interpretations of texts. Such postmodern understanding of reality as texts and interpretations concurs with the hermeneutic phenomenological ontology of this paper because characters and their worlds are considered as one entity, namely, text (Seamor, 2000). "If everything is a text, and if reading, writing, and interpreting are comments upon comments (or interpretations of interpretations), the social scientist becomes an interpreter of other interpretations” (Hollinger, 1994, p. 102). Therefore, perhaps it is superfluous to distinguish truth and reality from lies and fiction because they are only fragments of the same text or entity. The anonymous narrator in Palmwijn eloquently asserts: "you cannot separate fabrications from the truth, just as you cannot separate light from the sun” (Van Dis, 1996, p. 180).

Postmodernism recognizes these fragmented realities as equally true and real, and it may therefore be criticized as "[...] paradoxically throwing out the baby—-the large historical narrative—with the bathwater — the philosophical metanarrative. Uncertainty, unpredictability, and unknown, however, do not necessarily equal nihilism, solipsism, or relativism” (Anderson, 1997, p. 36).

\section{Reality as a Dream of Paradoxes}

The transition between the mystification of reality and the postmodern proliferation of paradoxes is facilitated by the opaque and mesmerizing dimensions of dreams in the novels. The dream could be conceived of as postmodern literary device because it is used to "present the existence of something unpresentable" (Lyotard, 1992, p. 11). Dreams can be used to manifest that which is repressed or rejected by traditional means of communication (Malpas, 2005, p. 29). Dreams may appear incongruent and irreconcilable with conventional conceptions of reality, yet alternative interpretations may reveal latent, congruent meanings.

In Het theater de brief en de waarheid, the story endorses metaphysics as authorial power summons the 
two protagonists (Herbert and Magda) from the dead to deliver eulogies at each other's funerals. In a stoke of dramatic irony and paradox, both deceased characters contemplate the nature of the dream. Unaware of being dead the characters theorize the dream, and enthralled by the intricacy of what could be called a metadream or a lucid dream the reader begins to question the fictitious nature of reality. Herbert describes it as follows:

To kill time I wanted to pursue this line of thought, but the tranquillizer did its job and dragged me into the depths of a feverish dream that I shall not tell. Not because I don't what to share it, but because it is impossible to talk about a dream. When you dream everything seems normal, but when you wake up and tell your dream it sounds silly. Because the dream was not silly when you dreamed, you tell nothing else but the dream. But what do you actually tell? Well, I dreamed my untellable dream, and woke up at the sound of meowing. (Mulish, 2000, p. 42)

Although Herbert remembers his dream, the tension between dream and reality causes him to consider the dream as an event that cannot be verbalized because it may sound unintelligible (like the meowing of a cat) compared to the reality of the physical dimension. Magda on the other hand cannot remember the content of her dream; consequently, she wonders how it is possible to remember something that one has forgotten.

I must have fallen asleep because I dreamed, but I cannot remember what I dreamed. How is that possible? How then can I know that I dreamed? Nevertheless, I am certain of it, I feel the dream as a ball deep inside me, somewhere below my stomach. Despite my best efforts, I cannot make it visible. (Mulish, 2000, p. 78)

It is possible to suspend the tension between physical and dream dimensions. When seemingly illogical or paradoxical connections between a dream and physical existence are resolved, the dream becomes "real". For example, in Het lied en de waarheid, the disillusionment of World War II prompts Louise to declare that "it was more comfortable to remember what you had dreamed than to recollect events experienced while awake" (Ruebsamen, 2001, p. 380). The margins between physical and dream dimensions dwindle as the protagonist in Palmwijn recollects the horrifying experiences in an African desert through a mirage of ambiguity: "Sleep was not pleasant, images twirled through my mind. Again I saw the people I met in the desert: a procession over the hills, effervescent in the air, like in a dream, but it was not a dream” (Van Dis, 1996, p. 32). The memories of hardship then demolish the separation between dream and reality as confusion sets in: "That is how a memory turns into a dream. Or was it the opposite?” (Van Dis, 1996, p. 35). Similarly, the margins between dream and reality fade in Ontaarde moeders as the trauma of a rape causes Meijken to contemplate whether she is awake or asleep or caught in a dream or reality (Dorrestein, 1992, p. 36). Dreams occur to create alternative realities that could function as coping mechanisms for disturbing events. Alternatively, the mind may relegate unpleasant memories of physical reality to the subconscious mind; therefore, dreams could be understood as the subconscious repository of these suppressed memories.

Yet, dreams are not completely separated from the physical dimension. The following examples illustrate the reciprocity between physical and dream dimensions, and that both are fragments of the same existential text or entity. In De tuin der onschuldigen, Simone’s loneliness stimulates her imagination to conjure visitors to which Nora responds: "She is lying. She is telling a dream, not the truth" (Hemmerechts, 1999, p. 21). In light of the autobiographical suicide theme of Kameraad scheermes, Wieg merges dream and paradox to find existential worth: "I dreamed of my demise. This dream kept me alive. It cannot get crazier" (2003, p. 103). From the emic perspectives of Simone and Wieg, their dreams are true and real, yet an etic perspective may consider them as unreal or lies. Herein lies the paradox because one text is simultaneously real and unreal from different perspectives. 
At this point, it would be sensible to consider the meaning of paradox. A paradox is "an apparently self-contradictory (even absurd) statement which, on closer inspection, is found to contain a truth reconciling the conflicting opposites" (Cuddon, 1991, p. 677). Considering the postmodern perspective on fragmented fictitious realities, a paradox may be understood as a seemingly self-contradictory statement consisting of fragments of diverse realities; however, from a different perspective the paradox seems consistent.

The mortality paradox initiated by a dream leads Wieg to think that "over the lifespan of a person, death is simultaneously always and never topical. Mortality is equally real and unreal” (2003, p. 18). Although Wieg does not resolve the paradox explicitly, a possible interpretation can be found in Palmwijn: "Death was not death on the island, and gone was not gone; the past left behind too many signs” (Van Dis, 1996, p. 10). The absence of the deceased African refugees is indelibly present in the remains of a shipwreck so that the memories of their existence and demise cannot escape the present. As such, the sample literature illustrates that a "postmodern approach to history is neither reference for the past not a modern erasing of traditions and starting anew from a tabula rasa" (Kvale, 1992, p. 7). The sample novels illustrate that the ostensible solidity of the past, coalescence of the present, and sanguine fluidity of the future are embroiled in paradoxical relations that escape reification with every additional perspective and interpretation.

The apparent conflicting opposites of the paradox only cause discomfort because a myopic perspective negates an expanded sensibility. The inherent incongruity of fragmented fictitious realties and the dreams of paradoxes are compatible contradictions that could be understood with a postmodern sensibility in mind that recognizes reality as a plethora of paradoxical stories.

\section{Reality as Plethora of Stories}

The stories seem paradoxical because they can be delegitimized based on conventional logic. However, the notion that stories construct and shape a postmodern ontology jeopardizes such logic. This section illustrates that while universal metanarratives are discredited, local narratives become self-legitimizing resulting in a profusion of stories that lead to the contemporary sense of unknowing and a condition called story shock.

The delegitimization of universal metanarratives is associated with the paradoxical nature of postmodernism. "Stories shape meaning in listeners and tellers, and so come to be believed as true; it is not that they are meaningful because they are true” (Young, 1997, p. 39). To live outside the shared stories of our time invites detachment, incoherence, and uncertainty. To live in the story landscape without recognizing one story as the authoritative, leading narrative creates a perspectival reality of multiple possible narratives. Because of the delegitimization of dominant narratives, local narratives gain equal recognition. Consequently, the local narratives account for the realities of the subjugated subaltern. Accountability contributes to the demarginalization of individuals and groups that are being called the Other (Bertens, 1995, p. 7). "Many such individuals account for their historic predicament as well as for their present struggles by positing a conspiracy of heterosexual European males” (Parry \& Doan, 1994, p. 142). It is therefore not surprising that postmodern literature is characterized by an influx of minority accounts such as the following: feminist (Ontaarde moeders and De tuin der onschuldigen); immigrant (Kameraad scheermes); (post)colonial (De aanslag, Indische duinen, Palmwijn, and Sleuteloog); and queer narratives (De overval and Dubbelliefde).

A consequence of postmodernism is that personal stories become self-legitimizing. "A story told by a person in his/her own words of his/her own experience does not have to plead its legitimacy in any higher court 
of narrative appeal, because no narrative has any greater legitimacy than the person's own” (Parry \& Doan, 1994, pp. 26-27). For example, Wieg's (2003) narrative account of his personal struggle with major depression in Kameraad scheermes enables the author to come to terms with the condition whilst readers could simultaneously identify with such challenges. As such, Wieg's story co-constructs a complex network of interrelated stories among author, characters, and readers.

The postmodern story deliberately complicates and multiplies the realities that it creates by seamlessly merging autobiographical information with the stories of characters. In the novel Chaos en rumoer by Zwagerman (1997), the reader is introduced to the antagonist Ed Waterland who is a successful author (like Zwagerman). Waterland writes a story entitled Het hart aan de rand van de stad about the protagonist Otto Vallei. Vallei is also an author, but he lives in the shadow of a writer's block phobia (a phobia shared by other writers). Chaos and rumoer is based on fragments of Zwagerman's autobiographical material. To save the story from a delegitimizing paradox, Vallei is asked to respond to the following: "You claim that it is your story and deny that it is your story. Save yourself from this” (Zwagerman, 1997, p. 167). To resolve this paradox, it would be prudent to understand the postmodern nature of stories.

Postmodernists maintain that life is a continuation of complex, unlimited stories. Stories are told and heard by all as they give direction to our lives. Stories do not copy life as much as they create life and eventually constitute realities: “[a story] is itself a situated action, a performance with illocutionary effects" (Gergen, 1994, p. 247). "With [supposed] fictions we investigate, perhaps invent, the meaning of human life” (Miller, 1990, p. 69). The ability of stories to create the world is emphasized in Souffleurs van de duivel: "[...] I realized that my grandmother's observations and recollections created her reality. Her reality was made up of stories, just like the realities of my parents and my own” (Wieg, 1996, p. 189). In similar vein, Mair eloquently describes the postmodern nature of stories as follows:

Stories are habitations. We live in and through stories. They conjure worlds. We do not know the world other than as a story world. Stories inform life. They hold us together and they keep us apart.

We inhabit the great stories of our culture. We live through stories. We are lived by the stories of our race and place. It is this enveloping and constituting function of stories that is especially important to understand more fully.

We are, each of us, locations where the stories of our place and time become partially tellable. We are in the story, and the story is in us. (Doan, 1998, p. 381)

The paradox that Vallei claims the story as his own, yet denies ownership, can be understood as follows: We all create, tell, inhabit, perform, and eventually become the postmodern story and the story of postmodernism. Although Vallei is the author of his story, "his story" or "history" is also the result of the interactions and co-constructions with stories authored by others. "Postmodern thought moves toward knowledge as a discursive practice [...]. It emphasizes the relational nature of knowledge and the generative nature of language” (Anderson, 1997, p. 36). As the network of stories burgeons because of the generative nature of language and the relational nature of knowledge, postmodernity is inundated with a "sense of unknowing" (Widdowson, 1999, p. 152) and diagnosed with a condition called "story shock" (Young, 1997). However, the plethora of stories nurtures multiple perspectives. "In the postmodern world we become increasingly aware that the objects about which we speak are not so much 'in the world' as they are products of perspective” (Gergen, 1991, p. 7). Consequently, the postmodern literary-based ontology generates alternative fragmented fictitious realities as Herter explains in Siegfried: "God is also only a story, but I am a polytheist, a 
heathen, I do not believe in one story, I believe in many stories” (Mulish, 2002, p. 24). Similar to Vallei in Chaos en rumoer, our individual ontologies emerge as a collection or "anthology" of stories collected from our own experiences, vicariously learned from others, or borrowed from our collective being.

\section{Conclusion}

The turmoil associated with the advent and growth of postmodernity set the backdrop for the exposition of a postmodern literary-based ontology that emanated from the research framework and discussion. This resulted in an interpretation of reality as fragments of fiction, reality as a dream of paradoxes, and reality as plethora of stories. From a modernist perspective postmodern realities may seem exceedingly relativist, indeterminate, and even schizophrenic (Malpas, 2005, pp. 7-8), yet the postmodern dimensions of reality reveal that the story that undermines itself or "blows itself up" (Zwagerman, 1997, p. 163) is as legitimate as universal metanarratives. The contradictory nature of a postmodern ontology challenges us to reconcile the opposite sides of paradoxes by assuming unexplored perspectives that yield alternative interpretations. Because the primary sources were novels, one may argue that the postmodern literary-based ontology was predisposed to identify reality as plethora of stories; ultimately, novels are stories. The novels, however, illustrate that the fragmented realties (theology, colonialism, psychology, and history, for instance) we create and inhabit are part of the pastiche-like collage and multidimensional story of our life (Bennett \& Royle, 1999, p. 238). Although the fragments are distinguishable, the hermeneutic phenomenological underpinning of this paper suggests that "people make sense of the world from the perspective of their realities and are not detached from the world" (Dowling \& Cooney, 2012, p. 24).

The postmodern literary-based ontology originated from the following challenges: the general neglect of ontology in the discussion of research frameworks in the social sciences, the difficulties that students experience to conceptualize ontologies, and the epistemological repercussions of postmodernism. The paper illustrated that a relatively accusable platform, such as the novel, can be used to extrapolate a personal philosophical framework. Identification with novels by a particular author or from a particular time or culture can be used to reveal the researchers natural propensity toward a particular philosophical tradition. This methodology to determine and express ones ontology agrees with Gadamer's notion of hermeneutic phenomenology (Dowling \& Cooney, 2012, p. 25). In this paper, the sample of novels suggests authorial comfort with Dutch socio-cultural and literary pursuits.

Although the sample of Dutch literature contributed to understanding a postmodern ontology derived from novels, the sample may also pose two limitations. Firstly, the novels may be discredited as unscientific sources, yet the hermeneutic phenomenological ontology does not dictate a hierarchical list of scientific sources. Secondly, Dutch novels may provide a particular Eurocentric perspective; however, as illustrated elsewhere, several novels explored minority perspectives that contributed to the notion of reality as plethora of stories. The Eurocentric perspective could also serve as inspiration for prolific comparative research. For example, the postmodern themes identified in Dutch literature could be compared with Postmodernism and Chinese Novels of the Nineties by Yiwu and Berry (1997). In response to the second motivation of this paper, subsequent research could also formulate pedagogical techniques to equip students in tertiary academic research-writing programs with the necessary literacies to formulate research-informative ontologies. The story of our time may be fraught with exhilarating and distressing events, yet this paper illustrates that a literary-based ontology serves as an empowering sense-making enterprise that peels away the layers of multiple realties and 
interpretations. Literature temporarily reifies and brings to understanding the vicissitudes of perpetually shifting realities to facilitate, create, and alter our individual and collective ontologies that lead to richer understandings of the self, others, and our existence.

\section{References}

Allesopeenrij. (February 26, 2015). Retrieved from http://www.allesopeenrij.nl/article.php?aid=27

Anderson, H. (1997). Conversation, language, and possibilities: A postmodern approach to therapy. New York: Basic Books.

Bennett, A., \& Royle, N. (1999). An introduction to literature, criticism and theory. London: Prentice Hall.

Bertens, H. (1995). The idea of the postmodern: A history. London: Routledge.

Brummett, B. (2009). Techniques of close reading. Thousand Oaks, CA: Sage.

Bizzocchi, J., \& Tanenbaum, J. (2011). Well read: Applying close reading techniques to game play experiences. In Well played 3.0 (pp. 262-290). Pittsburgh, PA: ETC Press.

Cahoone, L. E. (1995). The ten modernisms. In G. J. Rossouw (Ed.), Life in a postmodern culture (pp. 1-33). Pretoria: HSRC.

Claus, H. (1997). De geruchten (The rumors). Amsterdam: Bezige Bij.

Cohen, L., Manion, L., \& Morrison, K. (2005). Research methods in education. New York: Taylor \& Francis e-Library.

Creswell, J. W. (2014). Research design: Qualitative, quantitative, and mixed methods approaches. Thousand Oaks, CA: Sage.

Cuddon, J. A. (1991). Dictionary of literary terms and literary theory. London: Penguin.

Doan, R. E. (1998). The king is dead; long live the king: Narrative therapy and practicing what we preach. Family Process, 37(3), 379-385.

Dowling, M., \& Cooney, A. (2012). Research approaches related to phenomenology: Negotiating a complex landscape. Nurse Researcher, 20(2), 21-27.

Dörnyei, Z. (2007). Research method in applied linguistics. Oxford: Oxford University Press.

Dorrestein, R. (1992). Ontaarde moeders (Unearthed mothers). Amsterdam: Contact.

Dorrestein, R. (2002). Het geheim van de schrijver (The writer's secret). Amsterdam: Contact.

Eskridge, T. C., \& Hoffman, R. (2012). Ontology creation as a sensemaking activity. Intelligent Systems, IEEE, 27(5), 58-65.

Francken, E. (2001). Nieuwe momenten?: De Nederlandse roman na 1985 (The Dutch novel after 1985). Literator: Journal of Literary Criticism, Comparative Linguistics and Literary Studies, 22(1), 113-135.

Gergen, K. J. (1991). The saturated self: Dilemmas of identity in contemporary life. New York: Basic Books.

Giphart, R. (1999). De voorzitter (The chairman). Amsterdam: Rainbow.

Haasse, H. S. (2002). Sleuteloog (Keyhole). Amsterdam: Em. Querido’s.

Hemmerechts, K. (1999). De tuin der onschuldigen (The garden of innocence). Amsterdam: Rainbow.

Hollinger, R. (1994). Postmodernism and the social sciences. Thousand Oaks, CA: Sage.

Kirby, A. (2006). The death of postmodernism and beyond. Philosophy Now, 58, 34-37.

Kvale, S. (Ed.). (1992). Psychology and postmodernism. London: Sage.

LeVasseur, J. J. (2003). The problem of bracketing in phenomenology. Qualitative Health Research, 13(3), 408-420.

Liebenberg, W. (1988). Postmodernism: Progressive or conservative? Journal of Literary Studies, 4(3), 271-286.

Lopez, K. A., \& Willis, D. G. (2004). Descriptive versus interpretive phenomenology: Their contributions to nursing knowledge. Qualitative Health Research, 14(5), 726-735.

Lyotard, J. F. (1984). The postmodern condition: A report on knowledge (Vol. 10). Minneapolis: University of Minnesota Press.

Lyotard, J. F. (1992). Answer to the question: What is postmodernism? In The postmodern explained to children. London: Turnaround.

Malpas, S. (2005). The postmodern. New York: Routledge.

Miller, J. H. (2010). Narrative. In F. Lentricchia and T. McLaughlin (Eds.), Critical terms for literary study (pp. 66-79). Chicago: University of Chicago Press.

Mulish, H. (1998). De procedure (The procedure). Amsterdam: Bezige Bij.

Mulish, H. (2000). Het theater de brief en de waarheid (The theater, the letter, and the truth). Amsterdam: Bezige Bij.

Mulish, H. (2002). Siegfried: Een zwarte idylle (A black idyll). Amsterdam: Bezige Bij.

Ning, W. (2013). A reflection on postmodernist fiction in China: Avant-Garde narrative experimentation. Narrative, 21(3), 296-308.

Noonan, J. (2008). Ontology. In L. M. Given (Ed.), The Sage encyclopedia of qualitative research methods. (pp. 577-581). Thousand Oaks, CA: Sage. 
Palmen, C. (1995). De vriendschap (The friendship). Amsterdam: Prometheus.

Palmen, C. (1998). I.M. Amsterdam: Prometheus.

Palmen, C. (1999). De erfenis (The inheritance). Amsterdam: Prometheus.

Parry, A., \& Doan, R. E. (1994). Story re-visions: Narrative therapy in the postmodern world. New York: Guilford Press.

Peters, L. D., Pressey, A. D., Vanharanta, M., \& Johnston, W. J. (2013). Constructivism and critical realism as alternative approaches to the study of business networks: Convergences and divergences in theory and in research practice. Industrial Marketing Management, 42(3), 336-346.

Ruebsamen, H. (2001). Het lied en de waarheid (The song and the truth). Amsterdam: Contact.

Seamor, D. (2000). Phenomenology, place, environment, and architecture: A review of the literature. Phenomenology Online, 36. Retrieved

http://www.environment.gen.tr/environment-and-architecture/113-phenomenology-place-environment-and-architecture-a-rev iew-of-the-literature.html

Shotter, J. (1993). Conversational realities: Constructing live through language. London: Sage.

Smart, B. (2002). Key sociologists: Michel Foucault. London: Routledge.

't Hart, M. (2000). De zonnewijzer (The sundial). Amsterdam: Arbeiderspers.

Van Dis, A. (1994). Indische duinen (Indian dunes)). Amsterdam: Meulenhoff.

Van Dis, A. (1996). Palmwijn (Palm wine). Amsterdam: Meulenhoff.

Van Dis, A. (1999). Dubbelliefde (Double love). Amsterdam: Meulenhoff.

Vermeulen, T., \& Van den Akker, R. (2015). Utopia, sort of: A case study in metamodernism. Studia Neophilologica, 87(sup1), 55-67.

Widdowson, P. (1999). Literature. New York: Routledge.

Wieg, R. (1996). Souffleurs van de duivel (Prompters of the devil). Amsterdam: G. A. van Oorschot.

Wieg, R. (1997). De overval (The raid). Amsterdam: Arbeiderspers.

Wieg, R. (2003). Kamaraad scheermes (Comrade razor). Amsterdam: Arbeiderspers.

Winch, P. (2008). The idea of a social science and its relation to philosophy. London: Routledge.

Yiwu, Z., \& Berry, M. (1997). Postmodernism and Chinese novels of the nineties. Boundary 2, 247-259.

Young, G. (1997). Adult development, therapy, and culture: A postmodern synthesis. New York: Plenum Press.

Zwagerman, J. (1997). Chaos en rumoer (Chaos and disorder). Amsterdam: Arbeiderspers. 